\title{
Radon Concentration and Its Ventilation Dependence Measured in Some Dwellings of Debresina, Ethiopia
}

\author{
Abiy Tamiru Beshah", Tesfaye Dagne Muhe \\ Department of Physics, Bahirdar University, Bahirdar, Ethiopia \\ Email address: \\ abtamiru@gmail.com (A. T. Beshah), tesfayedagne7@gmail.com (T. D. Muhe) \\ ${ }^{*}$ Corresponding author
}

\section{To cite this article:}

Abiy Tamiru Beshah, Tesfaye Dagne Muhe. Radon Concentration and Its Ventilation Dependence Measured in Some Dwellings of Debresina, Ethiopia. World Journal of Applied Physics. Vol. 5, No. 3, 2020, pp. 34-38. doi: 10.11648/j.wjap.20200503.11

Received: October 21, 2020; Accepted: November 4, 2020; Published: November 19, 2020

\begin{abstract}
Ionizing radiation has been proved a major stress that can induce carcinogenesis. Among these ionizing radiations the most significant one is radon which is a source of $43 \%$ of the annual dose averaged over the population of the world. If it is present in enhanced level beyond maximum permissible limit, it may cause lung cancer. In the present work a set of indoor radon measurements has been carried out in some houses of Debresina district, Ethiopia using cellulose nitrate LR-115 type-II plastic track detectors in the bare mode. The detectors were fixed in the houses for one month to be exposed with indoor radon from February to March 2018. Etching of detectors was done with $2.5 \mathrm{~N} \mathrm{NaOH}$ solution for 75 minutes at $60^{\circ} \mathrm{C}$ in the Soil physics laboratory and counting of tracks recorded was done using optical microscope in the Department of Earth Science, Bahirdar University. It is found that the value of radon concentration in those dwellings ranges from 12.24 to $251.94 \mathrm{~Bq} / \mathrm{m}^{3}$ with an average of $102.87 \mathrm{~Bq} / \mathrm{m}^{3}$ and standard deviation of $81.97 \mathrm{~Bq} / \mathrm{m}^{3}$. The annual effective dose rates are found to vary from 0.31 to $6.29 \mathrm{mSv} \mathrm{y}^{-1}$ with an average of $2.57 \mathrm{mSv} \mathrm{y}^{-1}$ and a standard deviation of $2.05 \mathrm{mSv} \mathrm{y}^{-1}$. The indoor radon concentration has been found to have strong correlation with the ventilation condition. Ventilated houses have shown less radon concentration than unventilated houses. Though most of the indoor radon concentration values measured are well within the recommended action level of ICRP, more than half of these values are above the new recommended level of WHO.
\end{abstract}

Keywords: Ionizing Radiations, LR-115 Type-II, Radon Concentration, Annual Effective Dose Rate, Ventilation Condition

\section{Introduction}

Ionizing radiation is the term used to describe the transfer of energy through space or through a material medium in the form of electromagnetic waves or subatomic particles that are capable of causing ionization in matter, that is, capable of changing neutral atoms into charged atoms, called ions, by removing, or sometimes adding, electrons [1]. Among natural existing ionizing radiations the most significant one is radon which is a source of $43 \%$ of the annual dose averaged over the population of the world [2]. Radon is naturally occurring radioactive gas formed during spontaneous disintegration of atoms belonging to the three radioactive decay series: the Uranium Series - parent U-238, the Thorium Series - parent Th-232 and the Actinium Series - parent Ac-227 [3]. Radon is a colorless, odorless, tasteless, and an invisible gas with a density of 9.72 grams per liter. It is about seven times as dense as air [4].

The main source of indoor radon is its immediate parent radium-226 in the ground of the site and in the building materials [5]. The outdoor air also contributes to the radon concentration indoors, via the ventilation air. Tap-water and the domestic gas supply are usually radon sources of minor importance, with a few exceptions. In most situations it appears that elevated indoor radon level originates from radon in the underlying rocks and soils [5].

Radon exposure is known to be the second leading cause of lung cancer after cigarette smoking [6,7]. The radioactive decay of inhaled short lived radon progeny in the respiratory tract results in the deposition of alpha-energy in the cells of the bronchial epithelium. Decay products can cause direct effect on the DNA structure and indirect effect due to the production of active chemical radicals in the vicinity of DNA [8]. 


\section{Description of the Study Area}

Debresina is located in the Northern part of Ethiopia, Amhara region, North shoa zone (Figure 1). It is about 190 kilometer far from the capital Addis Ababa. The study area lies between $9^{\circ} 50^{\prime}$ and $9^{\circ} 58^{\prime}$ North latitude and $39^{\circ} 44^{\prime}$ to $39^{0} 48^{\prime}$ East longitudes. It has about $2690 \mathrm{~m}$ altitude above sea level.

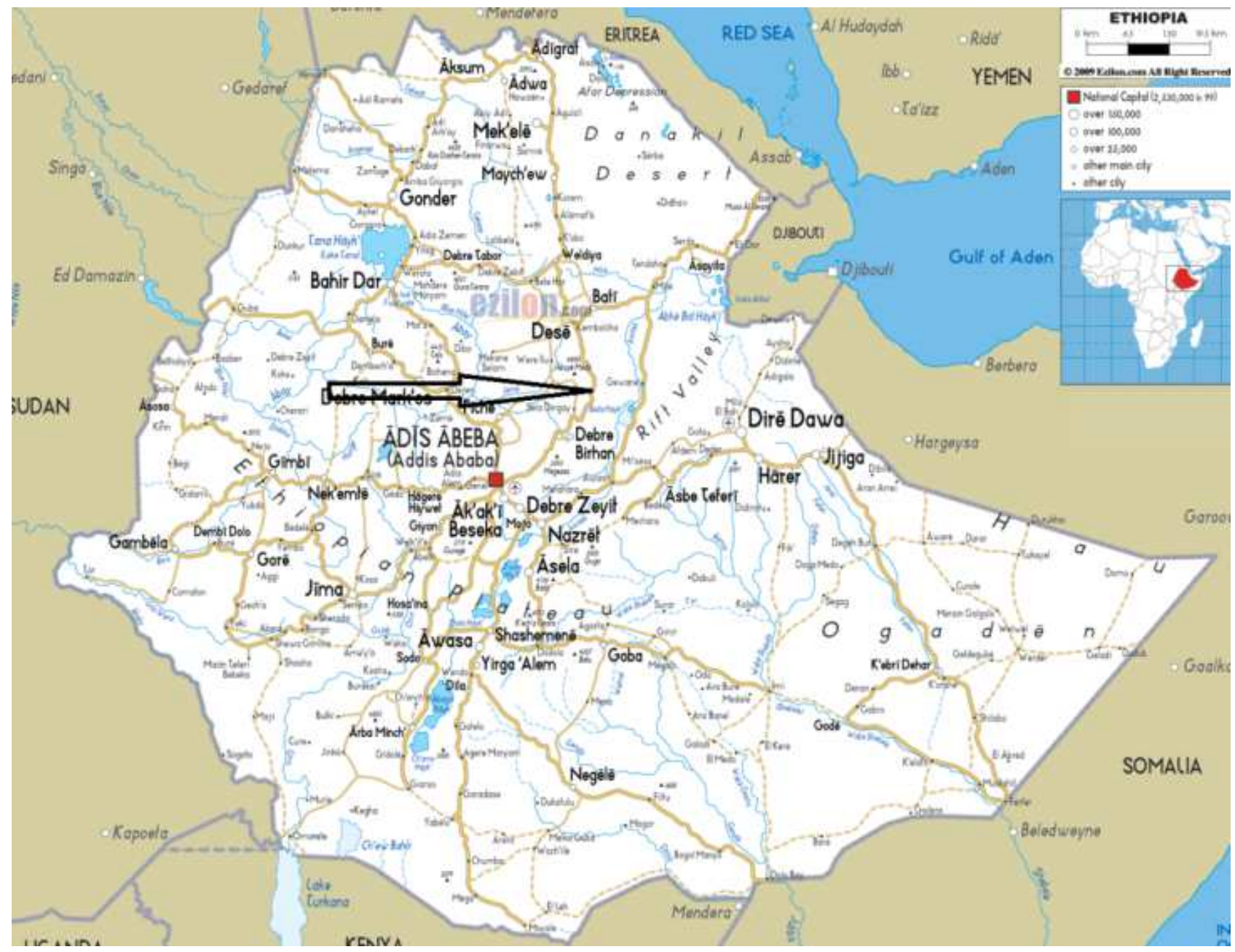

Figure 1. The location of Debresina in map of Ethiopia (taken from: https://www.ezilon.com/maps/africa/ethiopia-road-maps.html)

\section{Materials and Methods}

For measurement of radon levels in dwellings, LR-115 type-II solid state nuclear track detectors (SSNTDS) were employed. This plastic track detector (LR-115) is manufactured by DOSIRAD, Kodak Path France. The detectors are consists of $12 \mu \mathrm{m}$ red cellulose nitrate on a 100 $\mu \mathrm{m}$ clear polyester base. Due to its ruggedness and a fine window for recording alpha particles emanating from radon progeny, it is highly useful for integrated measurements from few days to several months. For measurements these LR 115 type-II plastic films were cut into smaller size $2.5 \mathrm{~cm} \times 3 \mathrm{~cm}$ by using sharp scissor. These pieces of detector were then fixed on thick flat card covering some part of the detector using adhesive tape putting the sensitive part outside. Having done this the size of the sensitive part of the film reduces to $2.5 \mathrm{~cm}$ by $2.5 \mathrm{~cm}$. The sensitive part of the detector was identified by scratching the surface using needle. By doing so we made the detectors ready to be fixed somewhere and make measurement.

The detectors were fitted in houses of different districts which were at least in 1 kilometer distance each. In each district 2 detectors were suspended in two different houses one in well ventilated and one in non-ventilated house. Ventilation condition of the houses was determined based on whether there is free air circulation or not. The houses which have windows and always remained open to let inflow of the outdoor air were taken as ventilated. While non-ventilated houses were the houses which have no windows and hardly their doors opened 1 hour a day. Once the detectors prepared, code is given at back of the card by writing a number. The date of distribution, collection and other related information were recorded in the note book. Then the detectors were mounted on walls of the room at height of about 1.5 meter from the ground in bare mode. After the exposure period of 1 month the detectors were brought back to the laboratory for analysis.

When a charged nuclear particle enters the plastic it creates a trail of radiation damage along its path. It is difficult to 
observe the direct evidence of this local damage, even under careful microscopic examination. However, this trail of radiation damage can be made visible through chemical etching of the material surface of the detector. The optimized conditions for etching of LR-115 type-2 detectors are: 2.5 normality of sodium hydroxide $(\mathrm{NaOH})$ solution at temperature range of $60^{\circ} \mathrm{C} \pm 1$ temperatures for 1 hour and fifteen minutes.

After the etching solution was prepared, it then poured in to coded beakers. After that the detectors were immersed into the beakers which were then kept into oven adjusted at temperature of $60^{\circ} \mathrm{C}$. During this time the solution was stirred in interval of 15 minutes to assure every part of the detector was etched. At the end of the etching, the detectors were taken out of the beaker and poured into pure distilled water for washing. After washing, each detector were dried and parceled into paper which was marked with the detectors code number. Finally the detectors were stored in a cool dry place for further investigation.

Then the tracks were counted using optical microscope by attaching squared hard transparent plastic on the detector surface in order to decrease counting error as illustrated in figure 2 .

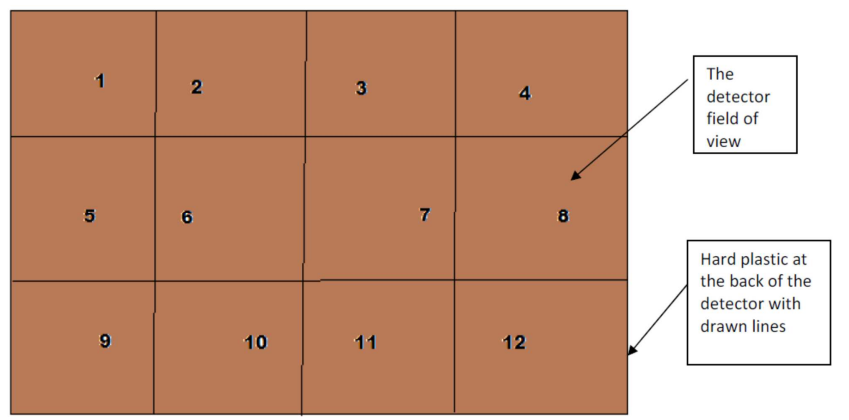

Figure 2. The field of view of the detector as seen by the microscope attached with hard plastic which is drawn onto rectangular shapes.
To measure radon concentration, we must calculate first the track density for each detector.

The track density is calculated using the relation:

$$
\rho=\frac{\text { total number of tracks }}{\text { area of detector }}
$$

In this study the area of track is taken $2.5 \mathrm{~cm} \times 2.5 \mathrm{~cm}=$ $6.25 \mathrm{~cm}^{2}$. The alpha energy concentrations (PAEC) are calculated using the following relation:

$$
C_{p}=\frac{\rho}{k . t}
$$

Where,

$\rho$ is the track density in tracks $/ \mathrm{cm}^{2}$,

$\mathrm{k}$ is the sensitivity factor or calibration factor in this study we take $\mathrm{k}=0.056 \mathrm{tr} . \mathrm{cm}^{2} / \mathrm{d}$ per $\mathrm{Bq} / \mathrm{m}^{3}$, and $\mathrm{t}$ is the total time of exposure [9].

At a certain radon concentration $\mathrm{C}_{\mathrm{Rn}}$ in $\mathrm{Bq} / \mathrm{m}^{3}$, the annual absorbed dose, $\mathrm{D}_{\mathrm{Rn}}$ is calculated in the unit of $\mathrm{mSv}$ from the following relation below:

$$
\mathrm{D}_{\mathrm{Rn}}(\mathrm{mSv} / \mathrm{y})=\mathrm{C}_{\mathrm{Rn}} \times \mathrm{D} \times \mathrm{H} \times \mathrm{F} \times \mathrm{T}
$$

Where,

$\mathrm{C}_{\mathrm{Rn}}$ is the measured $\mathrm{Rn}-222$ concentration (in $\mathrm{Bq} / \mathrm{m}^{3}$ ), $\mathrm{F}$ is the Rn-222 equilibrium factor indoors $(0.4), \mathrm{T}$ is the indoor occupancy time $24 \mathrm{~h} \times 365=8760 \mathrm{~h} / \mathrm{y}, \mathrm{H}$ is the indoor occupancy factor (0.8), and $\mathrm{D}$ is the dose conversion factor $\left(9.0 \times 10^{-6} \mathrm{mSv} / \mathrm{h}\right.$ per $\left.\mathrm{Bq} / \mathrm{m}^{3}\right)$ [9].

\section{Results and Discussion}

\subsection{Distribution of Radon Concentration}

The results of indoor radon concentration measured in 11 houses in Debresina district are reported in the Table 1.

\begin{tabular}{|c|c|c|c|c|}
\hline D. code & Ventilation type & $\rho\left(\right.$ in $\left.\mathrm{cm}^{2}\right)$ & $\mathrm{C}_{\mathrm{Rn}}\left(\mathrm{Bq} / \mathrm{m}^{3}\right)$ & Effective dose $(\mathrm{mSv} / \mathrm{y})$ \\
\hline $\mathrm{S} 1$ & Not Ventilated & 1188.57 & 231.69 & 5.79 \\
\hline $\mathrm{S} 2$ & Ventilated & 297.54 & 58.00 & 1.45 \\
\hline $\mathrm{S} 3$ & Ventilated & 62.79 & 12.24 & 0.31 \\
\hline S4 & Not Ventilated & 258.30 & 50.35 & 1.26 \\
\hline S5 & Ventilated & 183.91 & 35.85 & 0.88 \\
\hline S6 & Ventilated & 1292.45 & 251.94 & 6.29 \\
\hline S8 & Ventilated & 714.30 & 139.24 & 3.48 \\
\hline S9 & Not Ventilated & 527.52 & 102.83 & 2.57 \\
\hline $\mathrm{S} 10$ & Not Ventilated & 286.46 & 55.84 & 1.39 \\
\hline S11 & Ventilated & 67.20 & 13.10 & 0.33 \\
\hline Mean & & 527.72 & 102.87 & 2.57 \\
\hline Standard deviation & & 441.04 & 81.97 & 2.05 \\
\hline
\end{tabular}

Table 1. Potential alpha energy concentration (PAEC), concentration of radon and annual effective dose measured from some dwellings of Debresina (D. code... detectors code, V type... ventilation type, Cp... potential alpha energy concentration, CRn... radon concentration, and E. Dose... effective dose).

The table contains detectors code, ventilation type, track density, potential alpha energy concentration, radon concentration in $\mathrm{Bq} / \mathrm{m}^{3}$, and annual effective dose rate which were calculated using equations 1,2 , and 3 respectively. The mean and standard deviation are also calculated and tabulated. 


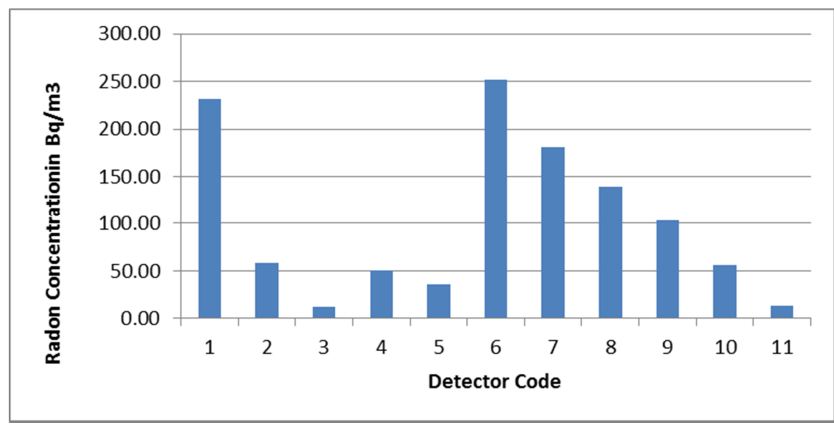

Figure 3. A bar graph showing the distribution of Radon concentration in $B q / m^{3}$.

The values of radon concentration range from 12.24 to $251.94 \mathrm{~Bq} / \mathrm{m}^{3}$ with an average of 102.87 and standard deviation of 81.97. The annual effective annual dose rates were found to vary from 0.31 to $6.29 \mathrm{mSv} \mathrm{y}^{-1}$ with an average of 2.57 and a standard deviation of $2.05 \mathrm{mSv}$ $\mathrm{y}^{-1}$.

International Commission on Radiation Protection ICRP65, (1993) has recommended that remedial action against radon and its progeny is justified above a continued effective dose of $10 \mathrm{mSv}$, while an action level within the range of 3$10 \mathrm{mSv} \mathrm{y}^{-1}$ has been proposed. The action level for radon concentration should be in the range between 200 and 600 $\mathrm{Bq} / \mathrm{m}^{3}$. In this study most of the measured values are below the above recommended action levels.

Although about $80 \%$ of the houses have radon concentrations below ICRP action level, about $30 \%$ of them have higher value than the reference level set by Environmental Protection Agency (EPA), $4 \mathrm{pCi} / \mathrm{L}$ or 148 $\mathrm{Bq} / \mathrm{m}^{3}$ and $55 \%$ of them are higher than the new reference level set by World health organization (WHO) of 100 $\mathrm{Bq} / \mathrm{m}^{3}$ [11] (figure 3). Also the average values of effective dose levels are found to be slightly higher than the average value of $2.4 \mathrm{mSv} \mathrm{y}^{-1}$ given by United Nations Scientific Committee on the Effects of Atomic Radiation (UNSCEAR).

\subsection{Radon Concentration and Ventilation Dependence}

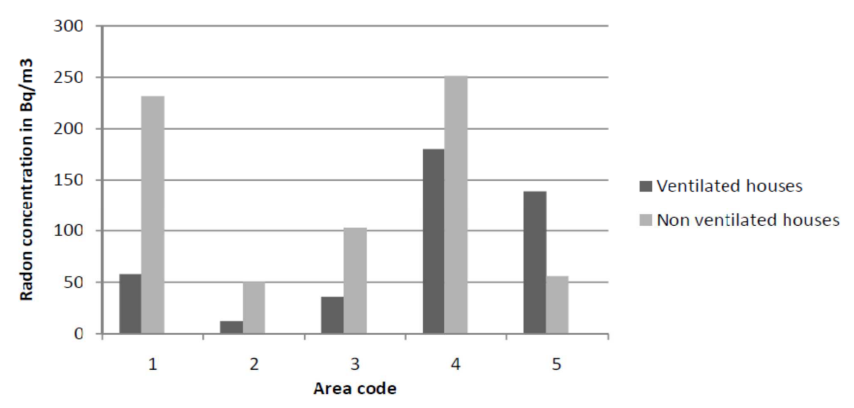

Figure 4. Bar graph shows comparison of radon level in Ventilated and nonventilated houses.

In order to see the ventilation effects the radon levels measured from the particular area with different ventilation effects compared. As it can be inferred from figure $4,80 \%$ of the concentrations of radon in non-ventilated houses are greater than that of ventilated houses in the same area. In contrary there is one house which shows higher radon concentration in well ventilated condition than its counterpart ventilated house. The higher values of radon concentration may be attributed to the granite stones used as building materials in the house.

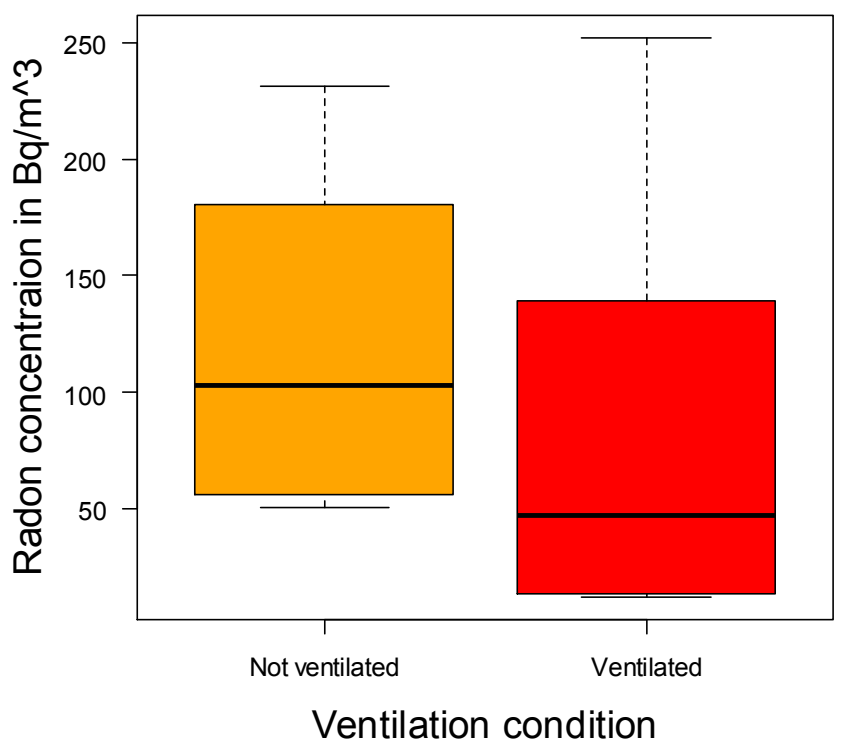

Figure 5. A boxplot showing a comparison of radon concentration based on the ventilation condition.

In the above box plot the radon level in ventilated housed ranges from $12.24 \mathrm{~Bq} / \mathrm{m}^{3}$ to $251.94 \mathrm{~Bq} / \mathrm{m}^{3}$ whereas in nonventilated houses it ranges from $50.35 \mathrm{~Bq} / \mathrm{m}^{3}-231.69 \mathrm{~Bq} / \mathrm{m}^{3}$. The median for ventilated houses is found to be $46.93 \mathrm{~Bq} / \mathrm{m}^{3}$ while $102.83 \mathrm{~Bq} / \mathrm{m}^{3}$ for non-ventilated houses. This result agrees with our expectation.

\section{Conclusions}

Most results of indoor radon concentrations are found to be well within the recommended action level (200-600 $\mathrm{Bq} / \mathrm{m}^{3}$ ) by the International Commission of Radiation Protection [12].

In this study some houses found to have high radon concentration. Appropriate remedial actions should be taken on those houses to reduce indoor radon concentrations. This may be done by making net like structure on the door or other openings which let exchange of air with the outside. Confirmatory tests should be made after mitigation to ensure that the lower radon concentration is maintained. Because radon concentrations undergo daily and seasonal variation, long-term radon tests (those detectors exposed in the home for more than 90 days) should be done to get more accurate results.

\section{Acknowledgements}

The authors greatly acknowledge the cooperation of the dwellers of the houses where the study took place. 


\section{References}

[1] Australian Radiation Protection and Nuclear Safety Agency (ARPANSA). (2002, March). RADIATION PROTECTION STANDARD (Radiation Protection Series no 1). Retrieved from:

https://www.arpansa.gov.au/sites/default/files/legacy/pubs/rps/ rps3.pdf?acsf_files_redirect

[2] IAEA (International Atomic Energy Agency). (2004, February). "Radiation, People and the Environment". IAEA/PI/A.75 / 04-00391.

[3] James E. Martin. (2006). Physics for Radiation Protection (pp. 288-296). Second Edition.

[4] EPA (Environmental Protection Agency). (1987, September). Radon Reference Manual. Office of Radiation Programs Washington DC 20460, EPA 520/1-87-20.

[5] Maregu N, Nebere L, Abeje N, Dessalegn B, Yibka T. (2019). Investigation of radon concentrations and effective radium content in soils and dwellings of Wolaita Sodo town, Ethiopia. J Radiat Cancer Res 10: 66-71. DOI: 10.4103/jrcr.jrcr_20_18.

[6] Nero A. V. Jr. (1989). Earth, Air, Radon and Home. Physics
Today. Vol. 42, 42 No 4 (April, 1989), page 32-39, ISSN 0031-9228.

[7] Castren O., Voutilainen, A. Winqist, K. and Miikelainen, I. (1985). Studies of high indoor radon areas in Finland, Sci. Total. Environ. 45, 311. DOI - 10.1016/0048-9697(85)90232-3.

[8] Wei Han and K. N. Yu. (2010). Ionizing Radiation, DNA Double Strand Break and Mutation. vol 4, ISBN 978-1-61728764-0.

[9] Singh A. K., Jojo P. J., Khan A. J., Prasad R. and Ramachandran T. V. (1997). Calibration of detector and measurement of radon exhalation rates from soil sample, Radiat. Prot. Environ. 20 (3): 129-133, ISSN 0253-6897.

[10] United Nations Scientific Committee on the Effects of Atomic Radiation. (2000). Annex B. UNSCEAR Report to the General Assembly. 1, UN, New York.

[11] WHO (world health organization). (2009). handbook on indoor radon: A public health perspective. Page 3-15, ISBN 9789241547673.

[12] ICRP. (2007). The 2007 Recommendations of the International Commission on Radiological Protection. ICRP Publication 103, Ann. ICRP 37 (2-4). DOI: 10.1016/j.icrp.2007.10.003. 